\title{
Dilemmas and Countermeasures in the Use of Construction Land in the Rural Tourism Development
}

\author{
Jiangtao Fang* \\ School of Law and Politics \& Trade, Chongqing University of Science \& Technology, Chongqing, China \\ *Corresponding Author.
}

\begin{abstract}
:
In recent years, the rural tourism industry in China developed prosperously, which effectively contributing to the implementation of the China Rural Revitalization Strategy. However, there are still many dilemmas in the development of rural tourism industry practices, such as excessive dispersal and poor operability of construction land use policies, lagging village planning, insufficient land use indicators, and housing site management policy restrictions. Accordingly, this paper analyzes the dilemmas in rural tourism development land use. Based on field investigation and literature analysis, the practices of land policy promoting the development of rural tourism industry are presented. The methods, case analysis, literature review, and empirical research are adopted in the research. The expected results that solving the dilemmas in land use are obtained through the combination of qualitative and quantitative analysis, including the integration and innovation of rural tourism land use policy, the rural tourism industry layout led by village planning, multiple strategies to protect tourism land index, and the speeding up of the rural collective construction land entry into the market. The above strategies could ensure the orderly development of new rural industries and new business forms such as rural tourism, and accelerate the implementation of China Rural Revitalization Strategy.
\end{abstract}

Keywords: Rural tourism, Construction land, Dilemmas, Countermeasures

\section{INTRODUCTION}

In 2017, the Chinese government clearly proposed the implementation of the rural revitalization strategy. At the beginning of 2018, the Chinese government issued the "Opinions on the Implementation of the Rural Revitalization Strategy", pointing out that the ultimate goal of rural revitalization is to achieve "strong agriculture, rural beauty and rich farmers". As the 
representative of the "sunrise industry" and "green industry", the rural tourism industry has developed rapidly and has become an important grasper for the implementation of the strategy of the rural revitalization strategy. However, due to various reasons, rural tourism land use still has difficulties, which restricts the development of rural tourism industry.

Many scholars have conducted in-depth research on rural tourism land. For example, $\mathrm{Wu}$ Guanxuan et al. discussed the rural tourism land circulation from the perspective of risk [1], and combed the research literature on rural tourism development and land transfer [2]. Based on the interaction between land transfer and rural tourism, Zhou Yang explored the specific path to promote development of rural tourism through land transfer by case analysis [3]. Xu et al discussed the problems of the planning of villages, the planning of rural in the era of interactive media, rural planning for industrial integration and development, and management of rural planning and construction [4,5]. From the legal perspective, Ren (2018) explored the issues of the land property rights in rural tourism land, land transfer, and made some countermeasures [6].

In order to ensure rural tourism and other rural industries development, the innovation and reform of rural land management policy system, which has become one of the issues of research. From the literature review, however, most researches focus on the problem of the utilization and the planning of agricultural land transfer. The study on the land use policy, construction land and planning in the rural tourism development, which need to be further research. On the basis of the implementation of rural revitalization strategy, this paper analyzes the dilemma faced by the development of rural tourism industry, and gives corresponding countermeasures. It can open up the bottleneck of policy implementation, accelerate the development of rural industry, and promote rural revitalization.

\section{THE DILEMMA OF THE UTILIZATION OF RURAL TOURISM CONSTRUCTION LAND UNDER THE RURAL REVITALIZATION STRATEGY}

Rural tourism has promoted the integration of primary, secondary, and tertiary industries in rural areas. It also accelerated the implementation of the rural revitalization strategy. Land is the carrier and guarantee of the integration of primary, secondary and tertiary industries. On the issues of tourism land use, China has repeatedly promulgated policies. However, the use of rural tourism construction land in China still ha difficulties in regulation and policy supply, village planning and land acquisition.

\subsection{Policy Dilemma: too Scattered, not very Operational}

In the process of promoting tourism throughout the country, China attaches great importance 
to the development of land use in the tourism industry. In 2009, in order to regulate tourism land, the State Council of China issued the "Opinions on Accelerating the Development of Tourism Industry". In 2014, the State Council of China issued the "Several Opinions on Promoting the Reform and Development of Tourism Industry", which proposed "optimizing land use in the tourism industry". Subsequently, the former Ministry of Land and Resources of China, the former China National Tourism Administration, Ministry of Housing and Urban-rural Development of China, and other 10 departments jointly issued the "Opinions on Supporting the Development of tourism land policy". It clarifies the relevant policies for the development of tourism industry land use, and standardize the use of rural tourism construction land also. In 2017, the former Ministry of Land and Resources of China issued the "Notice on Further Promoting the Structural Reform of Agricultural Supply Side and to Do a Good Job in Guarantying the land for Rural Industrial Integration and Development", which encourages to dish putting a quantity of collective construction land such as rural homesteads, and supports the rural tourism development. Under the guidance of national policy, rural tourism has developed rapidly. However, according to the actual situation, the rural tourism construction land use policy still has problems such as excessive dispersion and poor operationalist.

\subsubsection{The policy of rural tourism construction land is too decentralized}

In addition to the above policy document, the support policy of rural tourism construction land often appear in the comprehensive document on rural policies, which support measures are repeated. The publication and implementation of rural policies include the Government, the Ministry of Land and Resources of China, the Ministry of Agriculture, the National Tourism Administration. Zhongfa [2016] No.1 document and Zhongfa [2019] No.1 document clear support the development of rural tourism for rural house stead that is idle and abandoned. Due to the policy documents are issued by multi-sector, the actual operation departments at the grassroots level have some problem, such policy fatigue, insufficient attention, and cannot fully utilized the policy documents and support measures that have been issued.

\subsubsection{The operational of rural tourism construction land policy is insufficient}

In reality, tourism projects involve different land types, such as construction land, agricultural land, and unused land. It is not possible to determine the land price simply by "tourism land". However, there are some problems, such as the lack of supporting rules, the unclear mode of land supply, and the inability of social subjects to acquire the right to use after investment the results in insufficient willingness to vest in social capital. In addition, the lack of operability of policies is controversial for departmental management. The "Guidelines for the Implementation of Industrial Land Policy (2019 Edition)" pointed out that the land use of 
tourism, rural tourism parking facilities, et al, which can be managed in situ. That is to say, according to the guidelines, parking lots built on agricultural land in rural tourism development should continue to be managed by the agriculture and rural sectors. However, the planning and natural resources management department believes that if the land of parking facilities in rural tourism development is hardened and has the construction function, it should be managed according to the construction land.

\subsubsection{Lack of special supporting policies}

Insufficient rural tourism facilities, the construction of public facilities such as roads and road signs, environmental hygiene, the parking, water and electricity, phone service are lagging, and there is no special policy support.

\subsection{Village Planning Dilemma: Preparation Lag, not Enough Depth}

According to the space planning system of national land, the village planning is a multi-integrated plan for urban-rural planning and land use planning, and it is the "blueprint" for the layout of residential areas and industrial development land in the village. In recent years, with the proposal of new rural construction, the village planning is carrying out in some regions. Especially since 2019, China has put forward the requirement of "compiling practical village planning with multi-conformity". Local governments have accelerated the pace of the preparation of village planning. For example, Chongqing issued the "Guidelines for Rural Planning and Design in Chongqing (Trial)" in February 2019. However, from a general perspective, the village planning still cannot meet the development requirements of the rural tourism industry.

2.2.1 Rural planning lag. Some villages have basic conditions for the development of the tourism industry

For insufficient attention or funds, no village planning, and failure to achieve "planning, guidance and construction", the rural tourism has been developed within the scope of ecological protection zones and prohibited construction zones. It is illegal, and affects the compliance and sustainability of the development of the development of rural tourism industry.

\subsubsection{Insufficient depth of rural planning}

In June 2019, the China's State Council issued "Several Opinions on Establishing a Space Planning System of National Land and Supervising its Implementation”, which clearly stated 
that village planning serves as detailed planning. "The Notice of the General Office of the Ministry of Natural Resources of China on Strengthening Village Planning to Promote Rural Revitalization" clarifies that "village planning is a legal planning, a detailed plan for rural areas in space planning system of national land, and the legal basis for the development and protection of territorial space, the implementation of territorial space use control, granting planning permission for rural construction projects, and so on". But there are differences in understanding and implementation. For example, some villages have worked out village planning, but it is still in the guiding stage of planning. They do not consider the needs of the integration development of primary, secondary and tertiary industries, and lack of overall coordinated. Rural industrial projects such as rural tourism cannot be built on the basis of village planning.

2.3 Difficulties in Acquisition of Rural Tourism Construction Land: Insufficient Indicators and Policy Restriction

Rural tourism construction land can be obtained by transferring national land, or by transferring and leasing rural collective construction land. However, from the actual operation, it is still difficult to obtain rural tourism construction land according to the law.

\subsubsection{Insufficient construction land index}

China implements the policy of dual control of construction land planning and programmer. Even if in the line with the village planning, the rural tourism industry program needs to obtain new construction land indicator to develop and construct. At present, China's economic construction continues to develop rapidly, and urbanization continues to advance rapidly, and urbanization continues to advance rapidly. Local governments tend to give priority to the construction land index for industrial and urban construction, leaving relatively insufficient indicators for urban construction such as rural tourism. As far as Chongqing is concerned, there have been no cases of using the state added construction land index to deal with the procedures for land acquisition and transfer of rural tourism construction land. Meanwhile, the approval procedure of construction land is too complicated, and rural tourism project is difficult to land.

\subsubsection{The policy of rural collective construction land needs to be refined and improved}

For a long time, China has implemented the most stringent land use planning control and use control policies. Collective construction land such rural homestead cannot be transferred into the market, and cannot be directly used for industrial development and construction also. However, under the guidance of economic development and interests, the "invisible" market of rural collective construction land transaction has been flooded, which has attracted the attention of the 
government, such as "Wuhu Model", "South Sea Model", Chongiqng "Land Ticket". At the end of 2014, the state piloted the reform of the collective-operated construction land into market in 33 districts and counties throughout the country for a period of two years. In August 2019, "Law of the People's Republic of China on Land Administration" was amended to clarify that collectively-operated construction land can be traded on the market. However, what conditions are met is the rural collective-operated construction land, and how to realize that rural collective-operated construction land and state-owned construction land enjoy equal treatment, which needs further needs further refine the policy. In the development of rural industry such as rural tourism, the acquisition of rural collective construction land by means of sell, lease and transfer also needs to be further clarified and standardized by the state.

\subsubsection{Policy restrictions on homestead management}

On the one hand, the mechanism of revitalizing and utilizing rural homestead is not perfect. In the process of urbanization and industrialization, some peasants work in cities and towns, their income is stable and their residence is fixed, which leads to they do not live in the countryside for a long time. However, due to the imperfect mechanism of activating and utilizing the homestead, the rural housing has been idle and abandoned for a long time. On the other hand, the approval of farmers for building housed is too strict. In the examination and supervision of rural homestead, the "double control" policy of housing area and building area is implemented for farmers to build houses.

\section{COUNTERMEASURES FOR THE DILEMMA OF RURAL TOURISM CONSTRUCTION LAND UNDER THE STRATEGY OF RURAL REVITALIZATION}

The process of reform is not only the process of policy making and implementation, but also the process of finding problems and responding scientifically. In order to accelerate the development of rural tourism industry and promote the rural revitalization, the following countermeasures are put forward to solve the dilemma in the utilization of rural construction land.

\subsection{Integrate and Innovate Tourism Land Use Policies}

\subsubsection{Integration and refinement of tourism land use policy}

In view of the disadvantage of decentralized and inefficient operation of tourism land policies, local governments should integrate and improve the policies of the state and relevant departments, explore and innovate the path of land use reform, and publish normative 
documents publicly. By understanding a document, the township grass-roots governments can put the national policy on tourism land into practice. In 2017, the former Chongqing Land and Housing Management bureau, Chongqing Municipal Planning Bureau and Chongqing Municipal Tourism Bureau jointly issued the "Opinions on Supporting Tourism Development Land Policy", which clarified the tourism development planning, village planning supports rural tourism, differential management of tourism land, and land for tourism development. It is a typical example of integrating and refining the relevant tourism land policies of the state and various departments.

\subsubsection{Innovative land use management system}

In the reform of land management system, the urgent problem is clarify ownership and protect the rights and interests of stakeholders. For example, for rural tourism projects operated by agricultural enterprises, whose construction land is clearly defined as commercial construction land after the procedures for land acquisition and transfer. The reception houses and the legally acquired construction land invested by the total tourism project shall be registered according to the length of the lease land used by enterprises, which relieves the worries of the investor.

Meanwhile, it is necessary to increase policy support for the facility land of rural tourism. In the preparation of the national territory spatial planning, in order to meet the construction of tourism facilities such as rural tourism parking, it can reserve some construction land indicators, or link index increase and decrease of urban and rural construction land. If the parking facilities for rural tourism occupy agricultural land, but not destroying the tillage layer, such as paving permeable bricks and planting green plants, they may be management by the agricultural and rural departments in accordance with the provisions of the "Guidelines for the Implementation of Industrial Land Policies".

\subsubsection{Establish and improve relevant policies and measures}

Increasing support for infrastructure construction in rural areas, increasing investment in infrastructure construction such as communications, transportation and logistics in areas where rural tourism is developing rapidly, and intensifying efforts to consolidate domestic sewage treatment, road facilities construction and village appearance. At the same time, it is necessary to explore and establish a supporting policy system suitable for rural tourism development from the aspects of planning, land consolidation, rural tourism, financial subsidies, environmental consolidation and financial services, streamlining processes and integrating capital resources. 
In addition, it should vigorously develop rural industries such as intensive processing of agricultural products, modern circulation industry, and social services, and increase land use support measure. It needs to study and clarify the policy of years and prices of land use right for the rural tourism that use collective construction land in the form of equity and joint venture. In accordance with the requirements of establishing a "unified urban and rural construction land market", combined with the achievement of the benchmark land price pilot (such as Chongqing Dazu District), some counties with good land management foundation, strong rural integration of three industries, strong grass-roots leadership ability and a strong sense of collective operation be selected to carry out pilot projects for the development of unified urban and rural land grades and benchmark land price. Implement full coverage of benchmark land prices in the vast rural areas. On the basis of the pilot, explore the establishment of a technical system for the classification and valuation of collective construction land, which can provide a reference for collective land ownership or joint venture.

In order to promote the upgrading of rural tourism industry, form a series of new forms and products of rural tourism, and help farmer s to increase their income and rural prosperity, the government should improve policies, guide and encourage social capital to enter the field of rural tourism industry development, work with local rural collective economic organizations and farmers to build a project of integration f primary, secondary and tertiary industries, constantly improve the mode and benefit linkage mechanism of rural tourism in promoting the integration of rural industries.

\subsection{Leading the Layout of Rural Tourism Industry by Village Rules}

\subsubsection{Do a good job in village layout planning}

The implementation of the rural revitalization strategy is inseparable from the work of village planning, land use security policy, and agricultural industry project layout. Therefore, according to the principle of planning before construction, considering population agglomeration, land use, industrial development and ecological protection comprehensively, and according to the ideas of agglomeration promotion, suburban integration, characteristic protection, relocation and evacuation, the land for public service facilities, public infrastructure, industrial land, residential land and mixed land should be rationally allocated to promote rural revitalization by classification.

Meanwhile, to maintain the flexibility of planning, explore planning "blank" mechanism. That is to say, "blank" is temporarily reserved in the planning for the land that is difficult to define the specific use and nature. All localities are allowed to reserve a certain proportion of 
mobile indicators for construction land in village planning, which should define rules on the premise of meeting relevant provisions, and to land in the approval of construction projects. According to the regulations in Chongqing, the proportion of village planning elastic space in the total area of the planned village construction land should not exceed $30 \%$ in principle.

\subsubsection{Do compile practical village planning of "multi-planning"}

On the basis of "multi-planning", integrate the original village, village land use planning, and land comprehensive renovation planning, clarify the housing, environmental remediation, style control requirements of rural residential areas, and refine the planning requirements for public services, industrial development, social governance, and infrastructure in the village layout planning. Implementing the requirements of "conditional and demanding villages should be fully compiled" for village planning in the "Notice of the Office of Ministry of Natural Resource of China". Take Chongqing as an example. Chongqing stipulates that, if there is no condition for the preparation of village planning, it should analysis the current situation of land use; if the basic condition are available, the village planning guidelines or land use planning should be compiled; if conditions are good, practical village planning should be prepared. At present, $47 \%$ of villages and 4,200 villages in Chongqing have completed villages planning or land use compilation (Chongqing Planning and Natural Resource Bureau). Among them, the villages of Huaxi Village, Dingshan Village and Zhaishanping Village were selected as the first national rural planning excellent case organized by China Land Science Society in 2018. Meanwhile, in the process of compiling village planning, we should fully seek the opinions of villagers and market participants, force the planning to be compared with the actual economic and social development, and integrate with the rural primary, secondary and tertiary industries. We should put the spatial layout, industrial development and architectural style requirements determined by the planning into practice, strengthen the implementation of the planning, and promote the realization of "blueprint" of the planning and the coordination of rural production, life and ecological space.

\subsubsection{Good use policies such "dotted land use"}

Under the premise of adhering to national policies such as land use control, the land of new rural industrial and new forms of projects such as rural tourism should be ensured through the preparation of planning. On the basis of conforming to the general land use planning, it is allowed to optimize and adjust the land use layout in the village area through village planning, and make full use of the scattered stock of collective construction land. Reserve some construction land indicators for the construction of tourism facilities and agricultural facilities. At present, there are some successful cases of punctuate land development, such Hangzhou 
Mogansha Naked Valley, Chongqing Wulong Guiyuan Town, and Guangdong Panyu.

\subsection{Multi-channel Guarantee of Rural Tourism Construction Land}

\subsubsection{Guarantee land use index of rural tourism industry}

Take Chongqing as an example. According to the global tourism development planning, Chongqing uses the annual new construction land planning indicators, urban and rural construction land increase and decrease linked indicators, and land tickets to ensure the development of new construction land demand. For example, the "Notice of the Chongqing Planning and Natural Resources Bureau on the Issuance of New Construction Land Use Plan Indicators for the Integration of Rural Primary, Secondary and Tertiary Industries in 2019" stipulates that " 180 hectares of special projects for the primary, secondary and tertiary industries in rural areas should be arranged separately" to ensure the development of rural tourism and other industries. Chongqing also stipulates that the natural landscape land in the tourism industrial land is not collected (recovered) or transferred for use according to its original purpose. The land used for changing the use of agricultural facilities is protected by the annual planning index according to the management of the construction land. The land for non-profit public cultural facilities such as libraries and museums, as well as road squares, public transportation facilities and environmental sanitation facilities matched by tourism projects, shall be supplied by allocation mode with a single purpose and in accordance with the "Catalogue of Allocated Land". According to the management of construction land, the examination and approval procedures for land conversion of the land for operational facilities that should use land tickets or the indicators linked with the increase or decrease of urban and rural construction land.

3.3.2 Comprehensively promote the operation of collectively-operated construction land into the market

The "Guidelines for the Implementation of Industrial Land Policy (2019 edition)" explains land use policies in the fields of land use control, collective construction land management and new industry development. In August 2019, "Law of China on Land Administration" stipulated that collectively operated construction land could be traded on the market. It should seize the opportunity to study and promulgate the "Administrative Measures on the Transfer of Rural Collective Management Land Use Rights". At the level of national legislation, it should give clear support and reasonable regulation to the transfer and transaction of rural collective operating construction land, clarify and standardize the right to the use of collective operating construction land, the scope and way of entering the market, the rules of entering the market and 
the service supervision, the income distribution mechanism. It also regulates the use of collectively-operated construction land, such as stipulating that rural collectively-operated construction land can be used for tourism and commerce, and forbidding its use in real estate development.

At the same time, amending the provisions of the National Laws such "Constitution", "Law of China on Land Administration" and "Guarantee Law", which restrict and prohibit the transfer of rural collective construction land, and improving the definition of property rights and ownership rights of collective land in the "Property Law". To ensure the legitimacy of circulation and transaction of rural collective construction land, and to avoid the emergence of rural land market construction although in line with the policy but contrary to the law.

\subsubsection{Revitalize rural homestead and other construction land}

Rural collective economics organizations are allowed to collect land for homestead and township enterprises for the purpose of developing rural tourism. Meanwhile, to protect the rights and interests of collective economic organizations, the owner of collective land and the owner of the original homestead are allowed to apply to the real estate registration institution for the transfer registration of the land use rights after the approval of the village (town) government. Make full use of the idle farm house resources and develop and utilize the farm house and the surrounding farmland, to create "minshuku + farmland" rural tourism experience products. For example, Chongqing has combined the revitalization of housing resources with the integration of primary, secondary and tertiary industry in the rural areas, and adopted the method of "land based shares" and "joint venture with the housing" to start the work of Bayu minshuku in Chengkou Kanggu, Wuxi Changhong Village, Pengshui Dangyangzhai, and Youyang Nanmuwan. Make full use of the surrounding resources to create brand rural tourism. Until June 2019, Chongqing Bayu minshuku has received a total of 55,000 visitors, room revenue is about $2,200,000$ yuan, and sales of catering and agricultural special products is about 2,500,000 yuan (Chongqing Country Land Exchange).

Meanwhile, it should constantly standardize the examination and approval of farm housing construction. Under the premise of conforming to the planning adhering to the standard of "one family, one house" and the area of the homestead without breaking through, farmers are allowed to use the existing homestead to carry out centralized transformation of the original site of the farmhouse or the joint household to meet the needs of self-reside and develop rural tourism. 


\section{CONCLUSION}

The first-hand data were obtained through the investigation of land use and existing problems in the development of rural tourism industry in Chongqing. Combined with the literature review, it pointed out that the development of rural tourism industry urgently needed to solve the problem of construction land utilization, and give countermeasures. The specific conclusions are as following.

4.1 To Develop New Rural Industries such as Rural Tourism, it Needs to Integrate and Innovate Land Use Policies

On the one hand, local government should integrate and improve the policies of the state and relevant departments and innovate them in light of local actual conditions to promote the development of rural industries such as rural tourism in the region. On the other hand, it should increase policy support for rural tourism project facility land. For example, reserving some construction land indicators in the compilation of the national land space planning, or using urban and rural construction land increase and decrease linked indicator to meet the construction of tourism facilities such as rural tourism parking.

4.2 To Develop New Rural Industries such as Rural Tourism, it Needs to Play a Leading Role of Planning

Do a good job in village layout planning, prepare a practical village planning with "multi-planning", use policies such as "point land use" and explore the "blank" mechanism of planning. On the basis of conforming to the general land use planning, it is allowed to optimize and adjust the land use layout in the village area through village planning, and make full use of the scattered stock of collective construction land.

4.3 To Develop New Rural Industries such as Rural Tourism, it is Necessary to Guarantee the Land for Construction Land Through Multiple Channels

On the one hand, in order to protect rural tourism industrial land, use the annual new construction land planning indicators or urban and rural construction land increase and decrease linked indicators. On the other hand, it should comprehensively promote the trading of collective operating construction land into the market, and regulate the use of collective operating construction land, such as stipulating that rural collective operating construction land can be used for tourism and commerce, but strictly prohibiting its use in real estate. Meanwhile, it should revitalize construction land such as rural residential land, and allow rural collective 
economic organizations to collect the land for storage and township enterprises for the development of new rural industries such as rural tourism.

\section{ACKNOWLEDGMENTS}

The author is deeply indebted to the following research funds: (1) Chongqing Social Science Planning Project (Grant No. 2019BS048); (2) Research Foundation of Chongqing University of Science and Technology (Grant No. ckrc2019019).

\section{REFERENCES}

[1] Wu GQ, Niu X, Xu HZ (2013) Analysis on forming mechanism and management tools of land circulation risk during the development of rural tourism. Issues in Agricultural Economy 4: $63-68+111$

[2] Wu GQ, Niu X, Xu HZ (2013) The literature review of rural tourism develop and land circulation. Inquiry into Economic 1: 145-151.

[3] Zhou Y (2014) Land transfer and rural tourism development in China. Economic Management Journal 36(11): 124-133.

[4] Xu C (2019) The compilation and exploration of precise planning in mountainous rural planning - taking Zhaishanping village, Jiulongpo district, Chongqing as an example. Annual National Planning Conference, Dongguan, Guangdong, China.

[5] Xiao Y (2019) Study on the core problems and countermeasures of planning and construction management in Qiandongnan village", Annual National Planning Conference 2019, Dongguan, Guangdong, China.

[6] Ren Y (2018) Research on legal issues of rural tourism land under rural revitalization strategy. Journal of Southwest Jiaotong University (Social Sciences) 19(6): 32-33. 